\title{
An evolutionary approach to semasiological change: Overt influence attempts through the development of the Mandarin 吧-ba particle
}

\begin{abstract}
This paper focuses on the pragmatics of overt influence attempts (cf. Reich 2011, 2012; Tantucci 2016a) and their cognitive relationship with semasiological change. As a case study, the present analysis is centred on the recent history of the Mandarin 吧- $b a$ sentence-final particle, starting from the Qing Dynasty (1644-1911) up to its present day usage. Corpus-based data from the CCL Peking corpus highlight a progressive shift from an original directive usage towards a later assertive employment. In the latter case, speaker/writer 'invites' addressee/reader to agree with his/her statement on the basis of what is 'socially' or 'interpersonally' expected to be true/sensible. The cooperatively 'expected action' originally prompted by the particle, will then turn into cooperatively 'expected certainty' in later usages. From an evolutionary-psychological angle, at every stage of the cline it emerges the speaker/writer's consistent attempt to exert social influence on addressee/reader in the form of an 'interested' co-act proposal (cf. Reich 2011, Tantucci 2016b).
\end{abstract}

Keywords: overt influence attempt; intersubjectification; co-actionality; enactment; semasiology

\section{Introduction}

This paper proposes an evolutionary approach to address semasiological change (cf. Traugott \& Dasher 2002). Drawing on the so-called 'pragmatic-turn' in cognitive science (i.e. Varela et al. 1992; Noe 2004; Bowles 2006; Clark 2008) I argue that one important trigger of semasiological reanalysis is the speaker/writer's $(\mathrm{Sp} / \mathrm{w})$ attempt to exert influence on the addressee/reader $(\mathrm{Ad} / \mathrm{r})$ in the form of a co-action. This entails that the constructional/semasiological changes that intersect with the illocutionary force of a speech act are not merely symbolic, but crucially 'enactive' (cf. Engel et al. 2014), viz. dynamically aimed at exerting cognitive and social influence (cf. Reich 2011, 2012, Tantucci 2016a). Clearly, this does not entail a teleological motivation (cf. Croft 2000) for language change, but rather unveils cases where reanalysis occurs in contexts of overt influence attempts (OIA) (i.e. Reich 2011) from $\mathrm{Sp} / \mathrm{w}$ in the direction to $\mathrm{Ad} / \mathrm{r}$. This approach complements existing evolutionary models of language change (i.e. Croft 2000; Beckner et al. 2009) as it distinctively tackles Ad/r's agency as a decisive element of language innovation. 
As a case study, I provide corpus-based evidence from the Peking-corpus $\mathrm{CCL}^{1}$ suggesting that the usage Mandarin sentence-final particle 吧- $b a$ diachronically shifts from predominantly physical to new epistemic forms of co-act proposals (CAP). In the latter case, Sp/w's utterance is based on extended-intersubjectivity (cf. Tantucci 2013, 2017) and construes an 'interested' joint project at the epistemic level, rather than the physical one.

This paper is structured as follows: In section 2 I give a general overview of CAP theory and the new 'pragmatic turn' in cognitive sciences and evolutionary psychology. In 2.1 and 2.2 I illustrate how a CAP approach to language change may shed new light on underlying motivations of semasiology and intersubjectification. Section 3 is centred on the Mandarin sentence final particle 吧 $-b a$ and re-discusses it from a new enactive angle. Section 4 is dedicated to a corpus-based enquiry about the semasiological change of 吧-ba from the Qing Dynasty (1644-1911) up to the present. This change instantiates as a form of actuation, viz. the spread of an already existing construction (e.g. De Smet 2012) and will impinge on two different construals of intersubjectivity: from an originally $\mathrm{Ad} / \mathrm{r}$ 's oriented one encoding immediate intersubjectivity I-I, to a more recent 3rd party's oriented one, construing extended intersubjectivity E-I (cf. Tantucci 2013, 2015a, 2016b, 2016d; 2017; Guardamagna 2017; Van Olmen 2017).

\section{CAP theory and the enactive view}

The so-called co-act proposals (CAP) theory intersects with the recent so-called 'pragmatic-turn' in cognitive neuroscience, in which action and cognition are considered to be part of a continuum. CAP theory is first proposed in Reich $(2011,2012)$, where traditional speech acts are re-thought as overt influence attempts (OIA). OIA constitute "proposals or requests for the addressee to carry out a cooperative response" with a special focus on "how the agency of addressees is implied by the performance of many communicative acts" (Reich 2011: 1349).

This view is in opposition with the traditional Austinian-Searlean model of communicative acts (cf. Austin 1962; Searle 1969; Searle \& Vanderveken 1985) which posits that communication primarily aims at sharing meanings. Quite differently, the OIA model draws on evolutionary theory and emphasises that human communication is realised through co-act proposals (CAP), with the essential aim of exerting social influence. In this respect, the classic Austinian-Searlean model does not capture "the way in which a speaker [...] uses an overtly intentional signal to solicit cooperation from a hearer (addressee)" (Reich 2011: 1350). It is important to note that most activity in consciousness science and embodiment theory has traditionally placed great emphasis on the

\footnotetext{
${ }^{1}$ Http://ccl.pku.edu.cn:8080/ccl_corpus/. Last accessed: 19/03/2017.
} 
cognitive correlates of perception, independently of action. From a cognitive-linguistic angle, Schmid (2016: 543) stresses the need to integrate and operationalise social and pragmatic aspects in a cognitive-linguistic framework.

Crucially, recent studies from evolutionary psychology markedly emphasise the role of cooperation with conspecifics as a central trait of human evolution (Henrich \& Henrich 2007; Tomasello 2009). In the last two decades a new experimental agenda has been emerging in cognitive science, departing from traditional representation-centered and so-called 'spectator theories' (cf. Schilbach 2013) in the direction of 'enactive' cognitive paradigms subserving action and grounded in sensorimotor skills (cf. Varela et al. 1992; Noe 2004; Clark 2008; Engel et al. 2014). The enactive view of social cognition is built upon the following assumptions:

- Cognition is understood as the capacity to generate structure by action.

- The cognitive agent is immersed in its task domain.

- System states acquire meaning through their functional role in the context of action.

- The functioning of cognitive systems is thought to be inseparable from embodiment.

- A holistic view on the architecture of cognitive systems prevails, emphasizing the dynamic nature and context-sensitivity of processing.

- Models of cognition take into account the "extended" nature of cognitive systems.

(cf. Engel et al. 2014: 3)

Enactive cooperation is primarily rooted in the structure of communicative exchanges and individual communicative acts. This entails that "the shape of communicative acts and the way they assemble into larger units could be geared towards social cooperation, echoing the fact that they are devices which support coordinated activities" (Reich 2011: 1350). This perspective aims at "grounding social cognition in joint action (including, e.g. synchronized movements)" (cf. Engel et al. 2014: 9).

Co-act proposals (CAPs) are 'interested' forms of "joint projects" (cf. Clark 1996; Bangerter $\&$ Clark 2003). They are easily identified in contexts of 'language-for-action' so to say, where directive or interrogative communicative acts clearly show Sp/w's attempt to engage $\mathrm{Ad} / \mathrm{r}$ in some activity that can be beneficial for his/her, them and/or for a larger group of people:

(1) Leave me alone!

[Uttered by ex-girlfriend]

Possible paraphrase of conveyed CAP: Walk-away .

(2) Can you pass me the salt? 
[Uttered by mom at dinner]

Possible paraphrase of conveyed CAP: Pass-mom-the-salt.

Imperative gestures/utterances as the one given in (1) "exhibit perhaps the simplest possible relationship between the 'usage' of another human being as an 'agent tool' and the communicative act necessary to recruit him for this purpose" (Reich 2012: 1357). The CAP-concept extends smoothly from directives to simple interrogative gestures/utterances (cf. Bates et al. 1998 on the gradient relationship between the two).

Interestingly enough, the OIAs of CAPs also come into play when constative forms of communicative acts are realised, viz. the ones that are characterised by "information transmission" (Kissine 2013: 3). In the real example below, A utters an evaluational CAP I think p, viz. a constative expression in which s/he makes an evaluation that s/he expect Ad/r will endorse (cf. Tantucci 2016a). From an enactive perspective, the perlocutionary effects (cf. Searle 1969) of epistemic modal evaluations are the ones of persuading $\mathrm{Ad} / \mathrm{r}$ to indulge in the same belief that is conveyed by Sp/w. This fact is confirmed with the frequent co-occurence of $I$ think with the final negative interrogative isn't it. If the former were only aimed at sharing information independently form $\mathrm{Ad} / \mathrm{r}$ 's potential 'epistemic agency', then $\mathrm{Sp} / \mathrm{w}$ would not be interested in encouraging $\mathrm{Ad} / \mathrm{r}$ to endorse $\mathrm{p}$.

A: You know you you m-- you might be able be a little bit blameworthy in some instances?
A: Yes?
B: $\mathrm{Mm}$.
B: Yes.
A: Yeah, I think that's true isn't it?

BNC FM1 53

In the dialogic-spoken section of the BNC there are 11.3 concordances per million words where $I$ think and isn't it co-occur, the collostructional attraction (cf. Stefanowitch \& Gries 2003; Gries 2015) between $I$ think and the construction [I think $\mathrm{p}$ isn't it?] is significantly high $\left(\mathrm{p}=1.828452 \times 10^{-57}\right)$. Collostructional analysis investigates the degree of attraction or repulsion of a lexeme (in this case $I$ think) by a particular slot ' $\alpha$ ' in a construct/construction, viz. [ $\alpha$ p isn't it?]. While this example is to illustrate that [I think $\mathrm{p}$ isn't it?] can indeed be considered as a holistic chunk, collostructional analysis 
is generally performed to compare a number of lexemes with one another and their degree of attraction/repulsion with respect to a construct(ion) $)^{2}$.

The case above supports the idea that co-actionality seems to be inherent and necessary in any communicative act, and cannot be detached by Sp/w's 'interested' per-locutionary effects that may result from his/her utterance. One of the main claims of this paper is that the latent overt influence attempts (OIAs) that characterise the employment of a construction diachronically tend to shift from physical to new 'interested' epistemic forms of co-actional endeavours.

\subsection{CAP and semasiology}

Addressed from an OIA angle, this study suggests that language change is constantly affected by $\mathrm{Sp} / \mathrm{w}$ 's 'interested' attempt to involve $\mathrm{Ad} / \mathrm{r}$ in a 'co-action', may it be on a physical or on an epistemic level. In this sense, I propose a cognitive/pragmatic approach to language change that is primarily centred on the 'expected' co-agency that underlies a speaker's employment of a construction through each stage of a diachronic process of semantic-pragmatic or grammatical re-analysis. Most importantly, this model is focused on co-actional interaction as a mechanism that is always geared towards some beneficial outcome from the point of view of $\mathrm{Sp} / \mathrm{w}$.

In section 4 corpus-driven evidence will show that newly encoded polysemies throughout a cline of change are consistently driven by Sp/w's motivation to affect Ad/r's physical, emotional or epistemic state of affairs. The main focus here is on the Mandarin modal particle 吧-ba and its semasiological reanalysis from physical to epistemic forms of co-actionality. This is preliminary illustrated in the two real examples below:

（4）一听婆子们给道喜，不觉面红过耳，说道：“你们去吧，道什么喜”。 yī tīng pózimen gěi dàoxǐ, bùjué miànhóngérguòér, shuōdào: "nǐmen qù ba, dào shénme xǐ" as hear women give congratulations involuntarily flush, say: "you go BA, say what congratulations

'As he heard those women's congratulatory words, he suddenly flushed and said: "Leave, come on, what sort of congratulations are you offering?"”.

CCL Qing Dinasty (1644-1911) \San Xia Jian

(5) 班固所谓象意, 大概是说的前一类会意字吧。

\footnotetext{
${ }^{2}$ A diachronic collexeme analysis based on the sentences final 吧-ba is given in section 4.5.
} 
bāngù suǒwèi xiàngyì , dàgài shì shuō de qián yī lèi huìyìzì ba

Bangu so-called picografic-meaning, approximately is say STR before one type ideographic character BA

'We can say that the so-called pictographic meaning defined by Ban Gu can be considered roughly equivalent to the ideographic type of characters that we mentioned before.'

CCL Contemporary $\backslash$ CWAC

As exemplified here, the shift from directive to assertive types of speech acts corresponds to a shift from physical to new epistemic forms of co-act proposals (CAP). That is, $\mathrm{Sp} / \mathrm{w}$ in (4) due to some blatant embarrassment gently invites $\mathrm{Ad} / \mathrm{r}$ to leave the room, yet positing his request as a shared activity. A similar form of OIA occurs in (5) where $\mathrm{Sp} / \mathrm{w}$ employs 吧- $b a$ inviting $\mathrm{Ad} / \mathrm{r}$, or any other reasonable mind, to endorse his/her conclusion in the form of a shared evaluation, here paraphrased as we can say that $\mathrm{p}$ (despite the formal register, even the latter can be rendered in English with the $\mathrm{DM}^{3}$ come on).

Finally, it is important to consider the role that behavioural expectations (i.e. Vidal 1998; Spencer-Oatey 2005) may play at the co-actional level in different social groups. Behavioural expectations are primarily accounted for in terms of conventionalised meta-knowledge (i.e. Terkourafi 2015) which is socially evaluative and "closely associated with values and/or beliefs, [it is] scalar in nature and very contextually dependent" (Spencer-Oatey 2005: 99). While co-actionality undeniably intersects with behavioural expectations at different levels (i.e. illocutionary, discursive, stylistic and so on), yet CAPs involve a higher degree of schematicity as they are ultimately reducible to 'interested' interactions with a 'useful' agent. In this sense, behavioural expectations indeed impinge on common ground (i.e. Clark \& Brennan, 1991; Koschmann \& LeBaron, 2003) and cultural awareness of prescribed, proscribed and permitted behaviour (cf. Spencer-Oatey 2005: 97). However, from an evolutionary angle they necessarily derive from co-actional interaction, which in turn underpins online goal-oriented behaviour where $\mathrm{Ad} / \mathrm{r}$ is always both an interlocutor and a resource.

\subsection{Co-actionality vs intersubjectivity}

A fundamental distinction needs to be drawn for the purposes of the ensuing discussion, namely the one between co-actionality and intersubjectivity. The former is always present in human communication, as we share meanings with the intention of making various sorts of Co-act proposals. Simply put, co-actionality is aimed at inducing $\mathrm{Ad} / \mathrm{r}$ in joining a physical/epistemic co-action,

\footnotetext{
${ }^{3}$ Discourse marker.
} 
whereby the completion of the task may simply turn the Ad/r into an "agent tool" (cf. Reich 2011: 1356). In this case, empathy and an intersubjective problematisation of $\mathrm{Ad} / \mathrm{r}$ 's mind are not necessary conditions for the realisation of a CAP. To varying degrees, the two clearly do often intersect in human exchanges, but still do need to be intended as separate phenomena.

Different from co-actionality, intersubjectification has to do with the formation of added polysemies to a construction at different stages of semantic/grammatical change (cf. Traugott \& Dasher 2002; Traugott \& Trousdale 2013) in which Sp/w conveys a marked awareness of what Ad/r's (or a third party) mental state. It is triggered by a codified intention of $\mathrm{Sp} / \mathrm{w}$ to communicate to $\mathrm{Ad} / \mathrm{r}$ his/her awareness of other persona(s) and their emotions, beliefs. In this sense, intersubjectivity does not entirely correspond to co-actional OIAs, as the latter underlie any speech act including at least one (real or abstract) interlocutor. In fact, from a merely co-actional perspective, interlocutors do not necessarily need to be problematised as 'sensitive' or 'thoughtful' individuals. It is beyond dispute that OIAs are evidently enacted at various degrees of the autistic spectrum and do not need a developed Theory-of-mind mechanism to be realised. On the other hand, intersubjectification has to do with the formation of ad-hoc stratifications of meaning in a construction that are precisely aimed at considering $\mathrm{Ad} / \mathrm{r}$ or a third party as an individual with potential emotional/epistemic reactions to the utterance.

This sub-distinction is captured in the literature in cognitive psychology with the dissociation between 'awareness' and 'adoption' of another person's mental states. That is, "simply knowing that someone's mental state differ from one's own is not necessarily the same as being explicitly aware of what the other person's mental state is". (c.f. Schneider et al. 2014, Bradford et al. 2015: 23). Consider the co-action below:

\section{(6) A: Where is the salt? \\ B: There.}

A engages with B through a co-act proposal (CAP) with the overt influence attempt (OIA) of asking him/her to help him/her finding the salt. The deictic there uttered by B construes joint attention whereby both A and B are cognitively involved in a co-action, namely the one of granting A the possibility to reach the salt. However, there in (6) can hardly be defined as an intersubjective construction as B is not markedly codifying his/her awareness of A's emotions or beliefs. This clearly does not entail that B is lacking of a theory of mind or a mindreading ability. Rather, from his/her utterance s/he simply does not purposely encode his/her awareness of B's face. 
Interestingly enough, the deictic there in both British and American English is yet undergoing a process of intersubjectification (cf. Lenker 2016) whereby Sp/w may purposely try to mitigate the negative impact of a positive face threatening act FTA (cf. Brown \& Levinson 1987):

(7) A: $[\ldots]$ has children which he has by his first wife, in my view and in the view of the great majority of people in this country

B: I don't think it's the majority, you're wrong there.

BNC HVC 340

In (7) above there functions as a DM through which B isolates a specific instance where A may be 'accused' to be wrong, with the conventional implicature that A is just wrong there, not in an absolute sense. Different from (6) above, the intersubjective there in (7) is not obligatory (it can be omitted), and shows a specific tendency to occur in sentence-final position, as part of a wider pragmatic construction [positive FTA there] (cf. Traugott 2012 on DMs, intersubjectification and periphery dislocation):

(8) $\quad[\operatorname{PFTA}(\mathrm{p})$ there $] \oplus[\mathrm{p} \top]$.

[you're wrong there $\oplus$ [you're wrong (in an absolute sense)]

To spell (8) out, a proposition p occurring in the form of a positive face threatening act (PFTA) intersubjectively marked with the sentence-final there, is in exclusive disjunction $\oplus$ (i.e. Hurford 1974) with the same proposition $\mathrm{p}$ being absolutely true $T$ in isolation. The conventional implicature of this is that $\mathrm{Sp} / \mathrm{w}$ tries to mitigate his/her act of disagreement and save $\mathrm{Ad} / \mathrm{r}$ 's face by overtly marking $\mathrm{p}$ (you're wrong) as exceptional (there). This emerging intersubjectified function is easily proved as the implied meaning [-(p T)] [you're not always wrong] is compatible with [PFTA(p) there] in (8a), but comparatively less coherent in absence of there as in (8b):

(7) a. B: I don't think it's the majority, you're not always wrong, yet you're wrong there.

??b. B: I don't think it's the majority, you're not always wrong, yet you're wrong.

(7a) as a whole corresponds to an assertive CAP as it conveys $\mathrm{Sp} / \mathrm{w}$ 's overt influence attempt to posit $\mathrm{p}$ as a fact to be acknowledged by $\mathrm{Ad} / \mathrm{r}$. In addition, it is also intersubjective as the DM there in $\mathrm{p}$ markedly expresses $\mathrm{Sp} / \mathrm{w}$ 's awareness of $\mathrm{Ad} / \mathrm{r}$ 's exceptional fallacy. There is thus used to overtly 
account for Ad/r's positive face, viz. his/her emotions and beliefs resulting from being socially exposed to a PFTA.

Finally, it is important to note that intersubjectivity is itself a gradient notion and may shift from 'immediate' to 'extended' construing of (an-)other mind(s). While immediate intersubjectivity (I-I) profiles the awareness of emotions/beliefs of a distinct individual who is generally present during the speech event (this is the case of (7a) above), extended intersubjectivity (E-I) in turn is based on the awareness of a general social persona's or 3rd party (3rdP) and his/her 'inferred' reactions to the utterance (cf. Tantucci 2013, 2015a, 2016b, 2016d; 2017). The shift from I-I to E-I tends to unfold unidirectionally along a cline of semasiological change and will be discussed in greater detail in the corpus-based study in section 4. Having now set apart the two notions of co-actionality and intersubjectivity, we can move to the co-actional change of the 吧-ba particle in Mandarin.

\section{3. 吧-ba in the literature}

The Mandarin sentence final modal particle 吧-ba derives from the completive marker 罢-ba, originally signalling the actional completion of an action or an event (cf. Chao 1968: 807; Sun 1999; Wang 2009). In its modern usage, the modal 吧- $b a$ is a polysemous construction, yet its main function is still under debate. It is somewhat surprising how different and diverse are the descriptions of this particle from the recent literature. Lü (1980) identifies a number of cases where 吧-ba may occur, including conjectures, expressions of uncertainty, inferential interrogatives, orders, requests, speech acts of agreement and other functions of politeness. With the aim finding some unity amid the diverse range of usages of 吧- $b a, \mathrm{Lu}$ (1984) proposes a general mitigating function of the particle. Yet, in most accounts 吧-ba is considered to function as a "marker of uncertainty" (cf. Hu 1981; Shie 1991; Shao 1996; Zhang 2013). In other cases it is also described as an imperative construction (Wang 1984). Li \& Thompson (1981) and Qu \& Li (2004) argue that the main usage of 吧-ba is the one of "soliciting agreement", while in a more recent account Xu (2007) describes it as a marker of "weak information transmission, which includes Ad/r's acknowledgment" (cf. 2007: 188). The following subsections 3.1, 3.2 will present the most influential accounts of 吧 $b a$ from the literature, while section 3.3 will propose a novel 'enactive' model of analysis to the particle. Section 4 is then centred on the semasiological reanalysis of 吧- $b a$ starting from the Qing dynasty (1644-1911) up to its present usage.

\subsection{The 'uncertainty' account}


Compatibly with Xu's account, 'uncertainty' can hardly correspond to the prototypical meaning of 吧- $b a$, as the latter shows a marked tendency to appear in contexts where $\mathrm{Sp} / \mathrm{w}$ conveys a high degree of confidence. Yet, the notion of 'weak information transmission' still appears to be problematic in assertive contexts where Sp/w employs 吧- $b a$ with a constative illocutionary force.

\section{（9）我说，你昨天晚上来过？不可能吧，昨天晚上下那么大雨，你怎么会来？}

wǒ shuō , nǐ zuótiān wănshàng láiguo? bù kěnéng ba , zuótiān wănshàng xià nàme dàyǔ , nǐ zénme huì lái?

I say, you yesterday evening come ASP? Not possible BA, yesterday evening down so bigrain, you how possibly come?

'Let me tell you, did you really come back yesterday evening? This is impossible, come on, yesterday evening there was such a heavy rain, how could you possibly return?'

(Xu 2007: 287)

（10） $[\ldots]$ 反正我随身带的流动资金，总不能少于二十万吧。

[...] fănzhèng wǒ suíshēn dài de liúdòng zījīn , zǒng bùnéng shăoyú èrshí wàn ba.

[...] anyway I follow-body STR flow capital, generally not less-than 2010000 BA

[...] 'anyway, when I bring money with me I never carry less than 200000 Yuan.'

(Xu 2007: 287)

In both examples (9) and (10), 吧-ba can be hardly interpreted as a marker of weak information transmission, let alone uncertainty. In both cases, $\mathrm{Sp} / \mathrm{w}$ may compatibly use 吧- $b a$ to even reinforce his/her degree of confidence towards $\mathrm{p}$ :

（9） a. 我说, 你昨天晚上来过? 不可能吧, 昨天晚上下那么大雨, 你怎么会来? 你就是没 来吧 ! 4

wǒ shuō , nǐ zuótiān wănshàng láiguo? bù kěnéng ba , zuótiān wănshàng xià nàme dàyǔ , nǐ zénme huì lái? nǐ jiùshi méilái ba

I say, you yesterday evening come ASP? Not possible BA, yesterday evening down so bigrain, you how possibly come? You definitely did-not-come BA

\footnotetext{
${ }^{4}$ All examples discussed
} 
'Let me tell you, did you really come back yesterday evening? This is impossible, come on, yesterday evening there was such a heavy rain, how could you possibly return? You definitely did not come back, let's be frank!

（10） a. [...] 反正我随身带的流动资金, 总不能少于二十万吧。相信我吧！

[...] fănzhèng wǒ suíshēn dài de liúdòng zījīn , zǒng bùnéng shăoyú èrshí wàn ba.

xiāngxìn wǒ ba.

[...] anyway I follow-body STR flow capital, generally not less-than 2010000 BA.

Trust me BA.

[...] 'anyway, when I bring money with me I never carry less than 200000 Yuan.

You can trust me'.

In addition to that, in the CCL 吧-ba felicitously co-occurs with adverbials of certainty such as 一定 -yíding 'certainly', 毫无疑问-hăowúyíwèn 'undoubtedly' and similar:

这种事情不应该发生在这里, 我想肯定是敌人的阴谋吧。

zhè zhǒng shìqíng bù yīnggāi fāshēng zài zhèlǐ , wǒ xiăng kěndìng shì dírén de yīnmǒu ba this type situation not should happen in here, I think surely is enemy STR plot BA

'This shouldn't be happening here, I think we can say that this certainly due to the enemy's plot.'

CCL Contemporary Xinhuashe 2004

（12）毫无疑问您是重审派吧，因为外国人都是重审派。 háowúyíwèn nín shì chóngshěnpài ba, yīnwèi wàiguórén dōu shì chóngshěn pài there-is-no-doubt you are revisionist BA, because foreigner all are revisionist 'There is no doubt you are a revisionist, we can say that all foreigners are revisionists.'

CLL Contemporary Zhuiyi Si Shui Nianhua

\subsection{The 'soliciting-agreement' account}

In line with Chao's 'advisative' account (1968: 80), Li \& Thompson (1981) observe that the semantic function of 吧-ba is “equivalent to that of the Don't you think so? or Wouldn't you agree?" tagquestions in English, with the effect of "soliciting the approval of the hearer with respect to the statement to which $b a$ is attached". (cf. Li \& Thompson 1981: 307): 
(13) 我们走吧。

wǒmen zǒu ba

we go BA

'Let's go!'

(14) 起来吧。

qǔlái ba

rise-come BA

'Let's get up'

(Li \& Thompson 1981: 307)

While this is undoubtedly true for speech events including a specific $\mathrm{Ad} / \mathrm{r}$, the same cannot be maintained when $\mathrm{Sp} / \mathrm{w}$ makes declarative use of 吧- $b a$ in monologic or written registers:

[With regard to some secret periodicals that used to be printed with a beautiful layout]

(15) 他们那些人总没有印刷厂吧。

tāmen nà xiē rén zǒng méiyǒu yìnshuāchăng ba

they that few people always not have press-hous BA

'Those people never had a printing house, we can say.'

CLL Contemporary Argumentative writing \Deng Xiao Ping Xuan

(15) above occurs as an assertive CAP in a piece of argumentative writing. 吧- $b a$ here occurs in a monological register and is clearly not functioning as a tag-question asked to a specific $\mathrm{Ad} / \mathrm{r}$ (as no one is there to back up Sp/w's argument). Rather, it encodes extended intersubjectivity (E-I), as $\mathrm{Sp} / \mathrm{w}$ posits $\mathrm{p}$ in the form of an assertion that $\mathrm{s} /$ he expects a 3 rd party $(3 \mathrm{drP})$ - may it be singular or plural, specific or generic (cf. Tantucci 2013, 2015, 2016b, 2016d, 2017) - would accommodate and support. Yet, it is important to emphasise that the meaning of (15) still semantically entails co-agency as in both (13) and (14). From an enactive point of view, $\mathrm{Sp} / \mathrm{w}$ in (13-14) directs a physical OIA to a specific $\mathrm{Ad} / \mathrm{r}$ in the form of a shared action, viz. let's get up, let's go (the same CAP would be expressed with the overt encoding of the second personal pronoun 你 $n \check{\imath}$ ). In a similar vein, 吧- $b a$ in (15) construes a type of fictive interaction (cf. Pasqual 2006) where Sp/w markedly posits $\mathrm{p}$ as something virtually open to 3rdP's comment. Here, Sp/w's OIA occurs no more on the physical, but rather on the epistemic level. As a result, the illocutionary force of 吧- $b a$ here is no more of a directive 
type, but rather corresponds to a constative with the invited inference (i.e.Traugott \& Dasher 2002) of Sp/w's assertion being endorsed by 3rdP (i.e. any other mind beyond $\mathrm{Ad} / \mathrm{r}$ ): anyone would agree that those people never had a printing house.

Interpersonal evaluations based on E-I clearly impinge on utterance-specific processes of categorisation. The latter may underpin (im-)politeness and interpersonal alignment as they involve "common-sense or ordinary knowledge we have about persons, and how we expect them to behave in the context of those relationships" (cf. Kádár \& Haugh 2013: 62). From an enactive angle, monologic usages such as (15) show that E-I construing also allows a conceptualiser to construe adhoc generalisations 'on-the fly', based on the assumption that $3 \mathrm{rdP}$ would agree upon what is said. EI may also intersect with normative frames of reference (NFR), which crucially relate to "the perception that others from the same social group would evaluate a person or relationship in the same way" (Kádár \& Haugh 2013: 64). Also in this case, the present model puts a special emphasis on how NFR are not only 'consulted' as cultural common ground information to be shared with Ad/r, but also purposely 'enacted' in the form overt influence attempts (OIAs).

\subsection{The enactive, rather than symbolic meaning of 吧-ba}

Crucially, what is constant in all usages of 吧- $b a$ is the OIA of encouraging Ad/r or $3 \mathrm{rdP}$ to engage in a co-action, either physical or epistemic. This is confirmed by the fact that any statement that is marked with 吧- $b a$ can be reinforced by critiquing the possible world where Sp/w’s CAP would not be endorsed:

（13）（a)我们走吧。干嘛还在家里工作呢?

wǒmen zǒu ba. gànma hái zài jiā lǐ gōngzuò ne

we go BA do-what still stay home in work NE

'Let's go! What's the point of still staying at home working?'

（14）（a）起来吧。干嘛还在床上躺着呢？

qǔlái ba. gànma háizài chuángshàng tángzhe ne

rise-come BA do-what still on bed up lay-down NE

Let's get up! What's the point of still laying on bed?',

（15）（a)他们那些人总没有印刷厂吧。哪里有钱自己买一家呢?

tāmen nà xiē rén zǒng méiyǒu yìnshuāchăng ba 
they that few people always not have press-hous BA

'Those people never had a printing house, we can say. How could they have the money to buy one on their own?'

In all cases above, the CAP [p 吧- $b a]$ is felicitously reinforced with a subsequent rhetoric question ending with 呢- $n e^{5}$. The latter is itself a modal particle, used as a "response to expectation". It carries the function of "pointing out to the hearer that the information conveyed by the sentence is the speaker's response to some claim, expectation, or belief on the part of the hearer" (Li \& Thompson 1981: 300). Clearly, the subsequent occurrence of a [p 呢-ne ? ] construction is due to the co-actional construing of $\mathrm{Sp} / \mathrm{w}$ 's OIA towards $\mathrm{Ad} / \mathrm{r}$. Simply put, $\mathrm{Sp} / \mathrm{w}$ here is enactively pushing $\mathrm{Ad} / \mathrm{r}$ to pursue a new project, i.e. finally leaving the house, getting out of bed or being convinced that those people did not have a publishing house.

Interestingly, from the CCL, the collostructional attraction (cf. Stefanowitsch \& Gries 2003) between the collexeme 吧- $b a$ and the whole construction [p 吧- $b a \circ \mathrm{q}$ 呢-ne ?] (q standing for a 7R word-span) is significantly high $(\mathrm{p}=0.002967656)$. This fact is important to illustrate that the main function of 吧- $b a$ seems to be the one of construing an 'interested' joint project, rather than merely functioning as a symbolic marker of Sp/w's modal attitude. The same account is valid for cases where 吧- $b a$ functions as a topic introducer, with the reanalysed meaning of marking a topic in the form of a "suggestion particle" (cf. Wiedenhof 2016: 241):

(16) Eh, 这个, 在国内吧, 这个尤其在北京, 这个风沙比较大对。

Eh zhè ge, zài guónèi ba , zhè ge yōuqí zài běijīng, zhè ge fềngshā bǐjiào dà ba

Eh, zhis CL, in contry inside BA, this CL especially in Beijing, this CL sandstorm quite big true

'Eh, I mean, in China let's say, eh, especially in Beiijng, eh, the sandstorms are quite strong, yes.'

(Wiedenhof 2016: 241)

Even in this case, the new topic is introduced through 吧-ba is marked co-actionally rather than symbolically, viz. as a topic that the interlocutors are both actively going to deal with, i.e. let's now engage with $\mathrm{p}$.

\footnotetext{
${ }^{5}$ This test is corpus-driven, see table 9 in section 4.5 for more details.
} 


\section{An enactive approach to semasiology}

Semasiological approaches to language change aim at answering a fundamental question: given the form-meaning pair L (lexeme) what changes did meaning Mof L undergo? (Geeraerts, 1997). Despite the form of $\mathrm{L}$ (its morphosyntactic and morphophonological properties) remaining constant or undergoing only minor morphophonological changes (in our case, the form of the particle 吧- $b a$ remains constant), yet it is possible to observe new polysemies and pragmatic functions through time. The semasiological model is schematically represented in (17) below:

(17) $\mathrm{L} \rightarrow\left[\begin{array}{l}\text { Form } \\ \mathrm{M}_{1}\end{array}\right]>\mathrm{L} \rightarrow\left[\begin{array}{l}\text { Form } \\ \mathrm{M}_{1}+\mathrm{M}_{2}\end{array}\right]$

(Traugott \& Dasher 2002: 25)

Crucially, concerning the cognitive motivations triggering language change on a large scale, most of the emphasis has been traditionally placed on the symbolic encoding of $\mathrm{Sp} / \mathrm{w}$ of his/her own (inter-)subjectivity. Most of the phenomena under enquiry have been addressed as semiotic functions to represent $\mathrm{Sp} / \mathrm{w}$ 's mind as a support of the propositional meaning of an utterance (i.e. Traugott \& Dasher 2002; Langacker 1990, 2006; Ghesquière \& Van de Velde 2011; Narrog 2012a, 2012b; Nuyts 2012; Traugott \& Trousdale, 2013; Tantucci 2015b, 2016c, 2017). While the vast literature on this issue has produced crucial advances in understanding the relationship between intersubjectivity and language development, this study provides a complementary framework to address semasiological change from a CAP perspective. By disentangling intersubjectivity and co-actionality and analysing them as separate phenomena, this work extends the range of effects that can be observed through a process of constructional reanalysis.

Simply put, codified meaning here is no more intended to be merely representative of a Sp/w's mind, but rather enactive of it, as meaning transmission is by default a form of 'interested' ongoing co-operation. A CAP approach to language change is not merely focused on how the illocutionary force of an utterance is accounted for symbolically. Rather, the focus here lies on the phenomenology of a speech act as a process of overt influence attempt. This entails that even constative speech acts (i.e. assertions, evaluations, evidential/presentative utterances and so on) are not 'disinterested' utterances simply intended to share meaning, but are also crucially aimed at exerting epistemic and ultimately social influence (cf. Reich 2011, 2012; Tantucci 2016a, 2016b). 


\subsection{A semasiological approach to the OIA of 吧-ba}

Concerning the history of 吧- $b a$, Lan (2004) endorses Chao (1968) while suggesting that the character was originally written as 罢- $b a$ and started its process of change during the Yuan Dynasty (12711368). As a completive verb, 罢/吧- $b a$ then turned into an post-verbal particle encoding the aspectual realisation of an event. At this point, Lan suggests that 吧- $b a$ moved to a sentence-final position functioning as a modal particle. Qi (2002) hypothesises a semasiological cline of change shifting from an earlier declarative function to a new directive one. Subsequently, it would then start to be used as an interrogative and finally acquire a most recent intra-sentence function of 'prosodic pause'.

Qi's path of semasiological reanalysis will be challenged by corpus driven evidence provided in the ensuing sections. In particular, it will emerge that the so-called declarative function of 吧- $b a$ appears to be more recent than respectively directive and interrogative ones. It will be possible to observe a significant shift from directive, to interrogative and finally to a later assertive usage. From an enactive angle, this is due to a modification of OIAs occurring in the physical domain in the direction of OIAs of the epistemic kind. This change will impinge on two different construals of intersubjectivity: from an originally $\mathrm{Ad} / \mathrm{r}$ 's oriented one encoding immediate intersubjectivity I-I, to a more complex 3rdP's oriented one, construing extended intersubjectivity E-I (cf. Tantucci 2013, 2016b, 2016c, 2017).

\subsection{Operational criteria of annotation}

To start with, in table 1 below is provided a corpus-driven classification of 吧-ba utterances occurring in three different time spans from the CCL, namely Qing Dynasty (1644-1912), the Minguo period (1912-1949) and finally the Xiandai period leading up to the present (a description of the datasets in provided in the quantitative section 3.2):

Illocutionary force

Directive

Negative-interrogative

Assertive

Topic-introducing
Metalanguage of the CAP

Come on, let's p!

$\mathrm{p}$, isn't that so?

We can say that $\mathrm{p}$

We can now talk about $\mathrm{p}$

Table 1. 
4 main types of illocutionary force can be operationally distinguished across the period considered, namely: directive, negative-interrogative, assertive and topic-introducing one. The metalanguage of the CAP of each is given in English in the second column. We can first consider an instance of the directive type:

\section{[Directive]}

\section{（18）大哥您有理，我没有理，咱们回三观庙去吧！}

dàgē nín yǒulǐ, wǒ méi yǒulǐ , zánmen huí Sānguānmiào qù ba !

old-brother you be-right, I not be-right, we return Sanguan temple go BA

'Brother, you're right, I am not, let's return to the Sanguan temple, come on!'

CCL Qing Dinasty (1644-1911) \San Xia Jian

Directive concordances of 吧- $b a$ are always compatible with the pre-verbal adverbial 快 kuài 'fast'. The latter is in fact the adverbial element with the highest mutual information (MI) and LogDice (cf. Rychlý 2008) values in a -5-1L collocation span with the 吧-ba in the Qing Dynasty sub-corpus from the CCL (see section 4.5 for a diachronic collexeme analysis of pre-verbal elements of 吧- $b a$ ). This is not surprising as directive 吧 $b a$-CAPs tend to occur in the physical domain, viz. Sp/w invites Ad/r to engage in some 'real' (often physical) activity, i.e. walking, going somewhere, talking and so on. Crucially, corpus-driven evidence from the present dataset (see section 4.3) shows that no other CAP among the ones listed in table 1 is always semantically/grammatically compatible with 快 kuài as a pre-verbal modifier.

\section{a. 大哥您有理，我没有理，咱们快回三观庙去吧！}

dàgē nín yǒulǐ, wǒ méi yǒulǐ , zánmen kuài huí Sānguānmiào qù ba ! old-brother you be-right, I not be-right, we fast return Sanguan temple go BA 'Brother, you're right, I am not, let's immediately return to the Sanguan temple, come on!'

Yet, directive 吧 $b a$-CAPs differ from negative-interrogative 吧 $b a$-CAPs in that they never occur in questions. They also differ from assertive 吧 $b a$-CAPs in that they are never answered with elliptic epistemic forms such as 是的 shide 'that's right'. Finally, they differ from topic-introducing 吧 $b a$ - 
CAPs as they do not occur in mid-sentence position. These corpus-driven criteria for the annotation of directive 吧 $b a$-CAPs are formally summarised in table 2 below:

$\begin{array}{ll}\begin{array}{ll}\text { Illocutionary } \\ \text { force }\end{array} & \begin{array}{l}\text { Metalanguage of Corpus-driven annotation } \\ \text { the CAP }\end{array}\end{array}$

\begin{tabular}{|c|c|c|c|c|}
\hline \multirow[t]{4}{*}{ Directive } & \multirow[t]{4}{*}{ Come on, let's $\mathrm{p}$ ! } & a. & $\begin{array}{l}\text { P may always co-ccur with the pre-verbal element 快 } \\
\text { kuài 'fast'. }\end{array}$ & $\checkmark$ \\
\hline & & $b$. & $\mathrm{P}$ ends with a question mark. & $>$ \\
\hline & & $c$. & P may be answered with 是的 shide 'that's right'. & $>$ \\
\hline & & a. & $\mathrm{P}$ is in sentence final position. & $\checkmark$ \\
\hline
\end{tabular}

Table 2 .

Annotation of directives.

Conversely, negative-interrogative (n-i) 吧-ba-CAPs are not always grammatical if preceded by 快kuài, they always end up with a question mark, they may be answered with 是的-shide and always occur in sentence-final position:

[Negative-interrogative]

（19） A: 这个家伙，大概没有睡好吧?

zhè ge jiāhuǒ , dàgài méi yǒu shuìhăo ba

this CL guy, roughly not sleep-well BA

'This guy doesn't quite look like he slept well, isn't it?'

$\mathrm{B}$ : 是的。

shì de

is ST

'It's true.'

CCL (1949-present) Dalu Zuojia \Jiazuo

The annotation criteria for $n-i$ utterances are given in table 3 :

\section{Illocutionary Metalanguage of Corpus-driven annotation force the CAP}




\begin{tabular}{|c|c|c|c|}
\hline \multirow[t]{4}{*}{$\begin{array}{l}\text { Negative- } \\
\text { interrogative }\end{array}$} & \multirow[t]{4}{*}{$\mathrm{P}$, isn't that so? } & $a$. & $\begin{array}{l}\text { P may always co-ccur with the pre-verbal element 快 } \\
\text { kuài 'fast'. }\end{array}$ \\
\hline & & $b$. & $\mathrm{P}$ ends with a question mark. \\
\hline & & $c$. & $\mathrm{P}$ may be answered with 是的 shide 'that's right'. \\
\hline & & $d$. & $\mathrm{P}$ is in sentence final position. \\
\hline
\end{tabular}

Table 3.

Annotation of negative-interrogatives

Assertive 吧-ba-CAPs cannot be always compatible with the pre-verbal 快-kuài, they do not end up with a question mark, they may always be answered with 是的-shide and tend to occur in sentencefinal position:

\section{[Assertive]}

（20）刀放脖子上的时候, 我要是躲开, 就太无勇了吧!

dāo fàng bózi shàng de shíhou , wǒ yàoshi duǒkai , jiù tài wúyǒng le ba

knife put neck on ST time I if dodge, then too coward ASP BA

'With a knife on my neck, if I did try to get out of the way, then I would be a real coward, come on!'

CCL (1949-present) Lao She \Sishi Tongtang

The annotation criteria for assertive 吧- $b a$-CAPs are given in table 4:

\begin{tabular}{|c|c|c|}
\hline $\begin{array}{l}\text { Illocutionary } \\
\text { force }\end{array}$ & $\begin{array}{l}\text { Metalanguage of } \\
\text { the CAP }\end{array}$ & Corpus-driven annotation \\
\hline \multirow[t]{3}{*}{ Assertive } & We can say that $\mathrm{p}$ & $\begin{array}{l}\text { a. P may always co-ccur with the pre-verbal element 快 } \\
\text { kuài 'fast'. }\end{array}$ \\
\hline & & $b . \quad \mathrm{P}$ ends with a question mark. \\
\hline & & c. P may be answered with 是的 shide 'that's right'. \\
\hline
\end{tabular}

Table 4.

Annotation of assertives 
Finally, topic-introducing 吧- $b a$-CAPs occur in mid-sentence position, they are not logical when answered with 是的-shide, they are not followed by a question mark and cannot always be premodified by 快-kuài:

[Topic-introducing]

（21）嫂子吧，嫂子没到这家来的时候就是姐姐。 săozi ba , săozi méidào zhè jiā lái de shíhou jiù shì jiějie

elder-brother's wife BA, elder-brother's wife not arrive this home DE time only is older-sister 'Take my elder-brother's wife, before she became part of our family she simply was an older sister.'

CCL Dangdai (contemporary) \Spoken $\backslash 1982$ Pekinese language survey

The criteria for identifying topic-introducing functions of 吧 $b a$-CAPs are given in table 5 below:

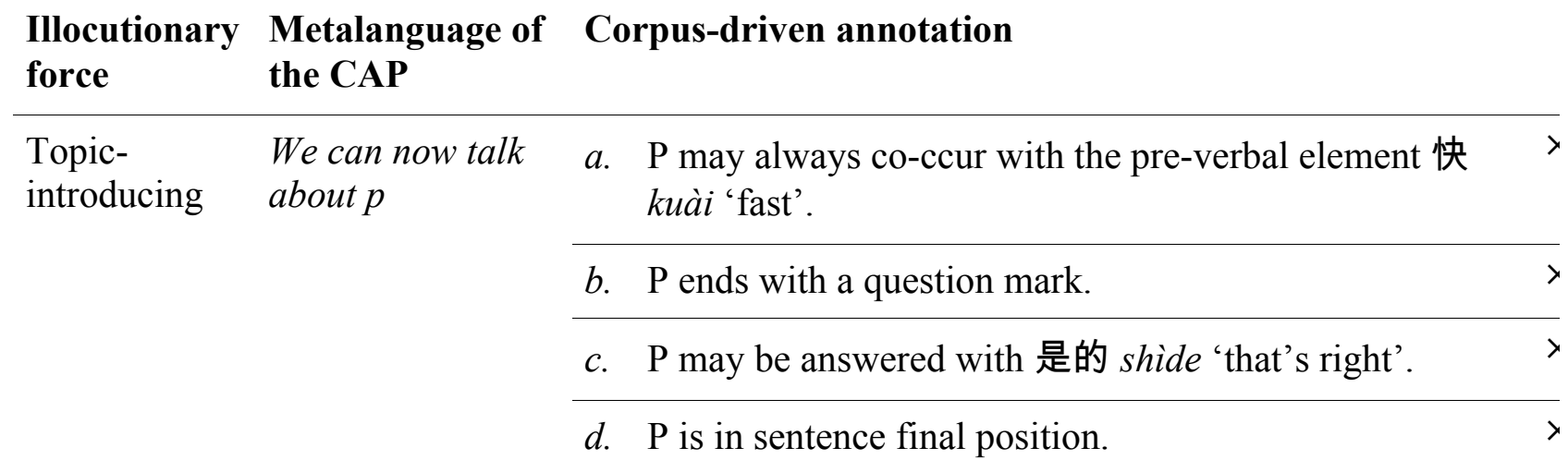

Table 5.

Annotation of topic-introducing

Having set the annotating criteria for this survey, it is now time to look at the semasiological change of the 4 CAPs above throughout the three periods considered.

\subsection{Corpus-based evidence of the semasiological change of 吧- $b a$}

This corpus survey is based on the the diachronic Peking corpus CCL (http://ccl.pku.edu.cn:8080/ccl corpus/). It contains both literary and vernacular materials which can 
be compared across its diachronic subsections. Periodised data from the three sub-corpora Qing Dynasty (1641-1911), Minguo Period (1911-1949) and Xiandai (1949-present) respectively include $48,109,077,35,371,339$ and $15,250,163$ words $^{6}$. The latter sub-corpus is also constituted by literary and vernacular texts as it is separated from the broader Dangdai section (contemporary) which comprises a more diverse variety of genres (i.e. spoken, blogs, media).

It is acknowledged that data from trials, plays, conversation in novels and letters tend to represent language relatively close to speech, and constitute a crucial resource for diachronic investigation (cf. Culpeper and Kytö 2010). Written language is a fundamental window to investigate language change (Traugott and Dasher 2002: 46) as "text provides a mode of speech" (Olson, 1994, p. xviii), and histories of words and constructions in the development of languages display wellattested reflexes in contemporary spoken data (Biber 1988). In this sense, gradient changes of meaning observed in diachronic re-analysis correspond to the sedimentation spontaneous innovation (cf. Traugott \& Trousdale 2013). The latter unavoidably reflects cognitive associations of meaning from earlier stages of language production which then became widespread within a large speech community. This clearly entails that data from diachronic investigation may critically inform cognitive analysis of online language production (cf. Croft 2000, 2007).

To compute the relative frequencies of the 4 different 吧 $b a$-CAPs (see table1), I adopted a similar methodology as the one proposed in Jing-Schmid \& Peng (2016). Namely, I first obtained from each sub-corpus a randomised sample of 200 concordances of 吧- $b a$ as the keyword. Through manual annotation (based on the operational criteria given in section 3.2) I obtained the raw frequencies and distributions of the 4 CAPs under enquiry from each randomised sample. Subsequently, I retrieved all the tokens of 吧-ba from each sub-corpus (Qing Dynasty, Minguo period and Xiandai), and normalised their per-milion-words (pmw) frequency. Finally, I computed the relative frequency of each function (i.e. directive, negative-interrogative and so on) in relation to the normalised frequency of 吧- $b a$ in each period. In table 6 below are given the raw frequencies of each usage in the three randomised samples respectively from Qing, Minguo and Modern period:

Qing (1644-1911)

Directive

Negative-interrogative

Assertive

Topic-introducing

\section{Minguo (1911-1949)}

171

17

9

0
139

17

32

3

\section{Modern (1949-present)}

\section{9}

22

74

12

\footnotetext{
${ }^{6}$ The list of all texts included in both the diachronic and synchronic sections of the CCL can be retrieved from the following website: http://ccl.pku.edu.cn:8080/ccl corpus/corpus info.pdf. (last accessed 27/07/2017).
} 
Table 6.

Raw frequencies of 吧- $b a$ from each randomised sample.

In Table 7 below is given the relative pmw frequency of each function throughout the 3 time-spans considered:

\begin{tabular}{|c|c|c|c|}
\hline & Qing (1644-1911) & Minguo (1911-1949) & Modern (1949-present) \\
\hline Directive & 62,9 & 62,6 & 152,6 \\
\hline Negative-interrogative & 6,2 & 7,6 & 37,7 \\
\hline Assertive & 3,3 & 14,4 & 126,9 \\
\hline Topic-introducing & 0 & 1,3 & 20,58 \\
\hline
\end{tabular}

Table 7.

Relative pmw frequencies of 吧- $b a$.

Data from table 7 can be visualised in Figure 1 below:

$\begin{array}{ll}\diamond \text { Directive } & \diamond \begin{array}{l}\text { Negative-interrogative } \\ \triangle \text { Overall pmw frequency }\end{array} \\ 400 & \square \text { Assertive }\end{array}$

300

200

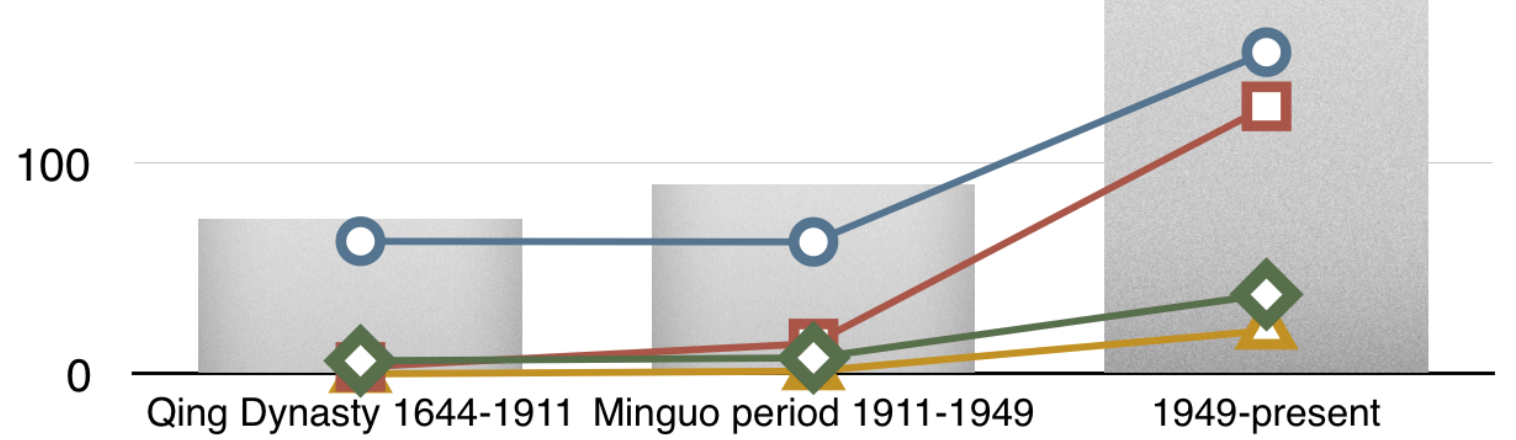

Figure 1.

Semasiological change of 吧-CAPs from the CCL 
On the $\mathrm{x}$ axis are given the three time-spans under investigation: (1644-1911; 1911-1949; 1949present), while the y axis accounts for pmw frequency values.

First thing to be noticed, the three charts in the background show that the normalised overall employment of 吧- $b a$ dramatically increases after 1949. More crucially, there is a striking increment of its assertive usage from the Minguo to the Modern period (from 14,4 to 126,9). This fact is important also in comparison with the negative-interrogative function, which was still more frequent than the assertive one during the earlier Qing Dynasty-span. Similarly, the relative frequency of topicintroducing functions shifts from 0 during the Qing Dynasty, to 1,3 during the Mingguo period, to a conspicuous 20,58 during the 1949-present span. Both the sharp increase of assertive and topic introducing usage of 吧- $b a$ from the 1949 onward is better captured in the corresponding bar chart in figure 2:
Directive
Negative-interrogative
Assertive
Topic-introducing

180

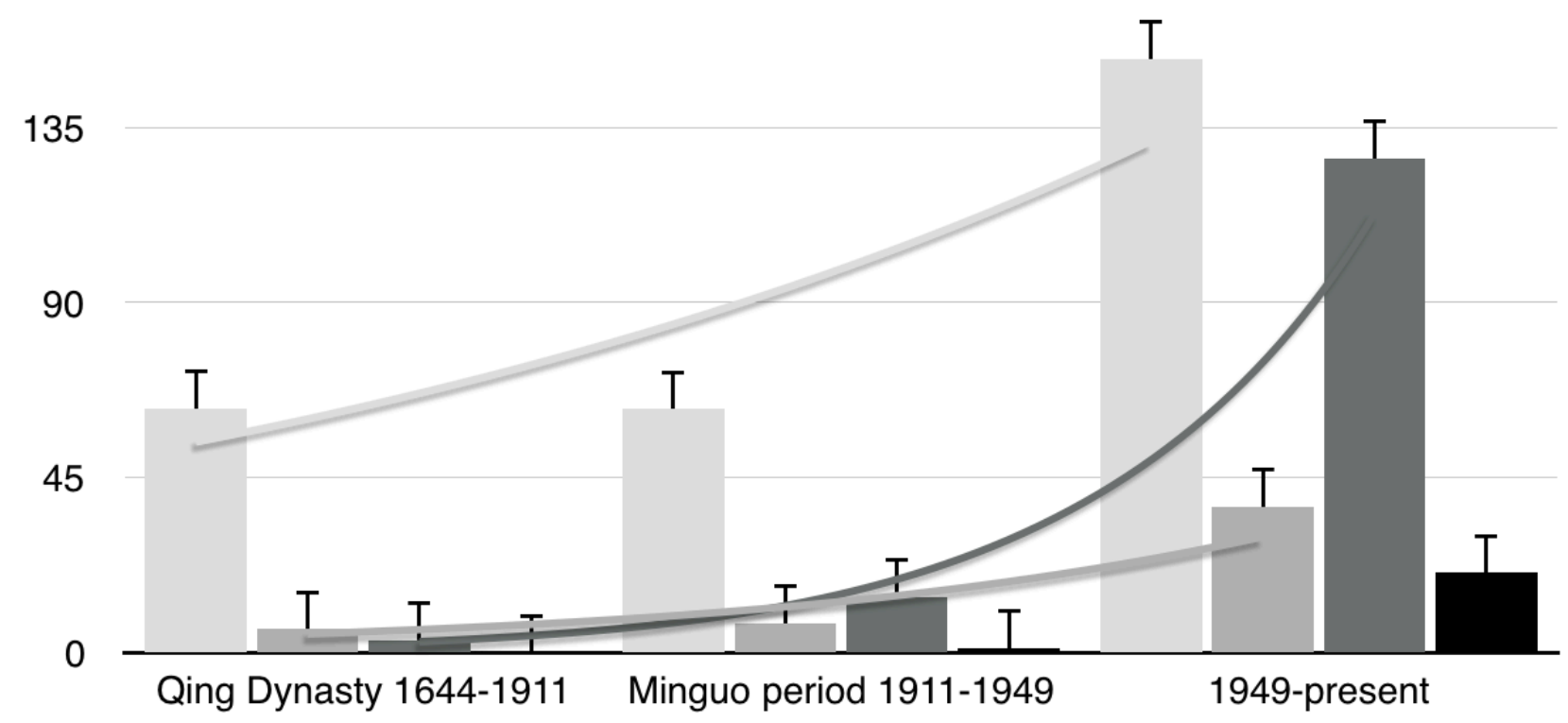

Figure 2.

Semasiological change and trendlines of 吧-CAPs from the CCL

The exponential trendlines from figure 2 highlight data values that rise at a constantly increasing rates $^{7}$. What is of interest here is especially the tight bend of the trendline referring to the assertive

\footnotetext{
${ }^{7}$ As the topic-introducing contains a zero value during the first period, an exponential trend line cannot be calculated for this specific function.
} 
employment of 吧- $b a$ in contrast with the directive one ${ }^{8}$. The increasingly even distribution of the two appears most evident in isolation from figure 3 below:

\section{Directive}

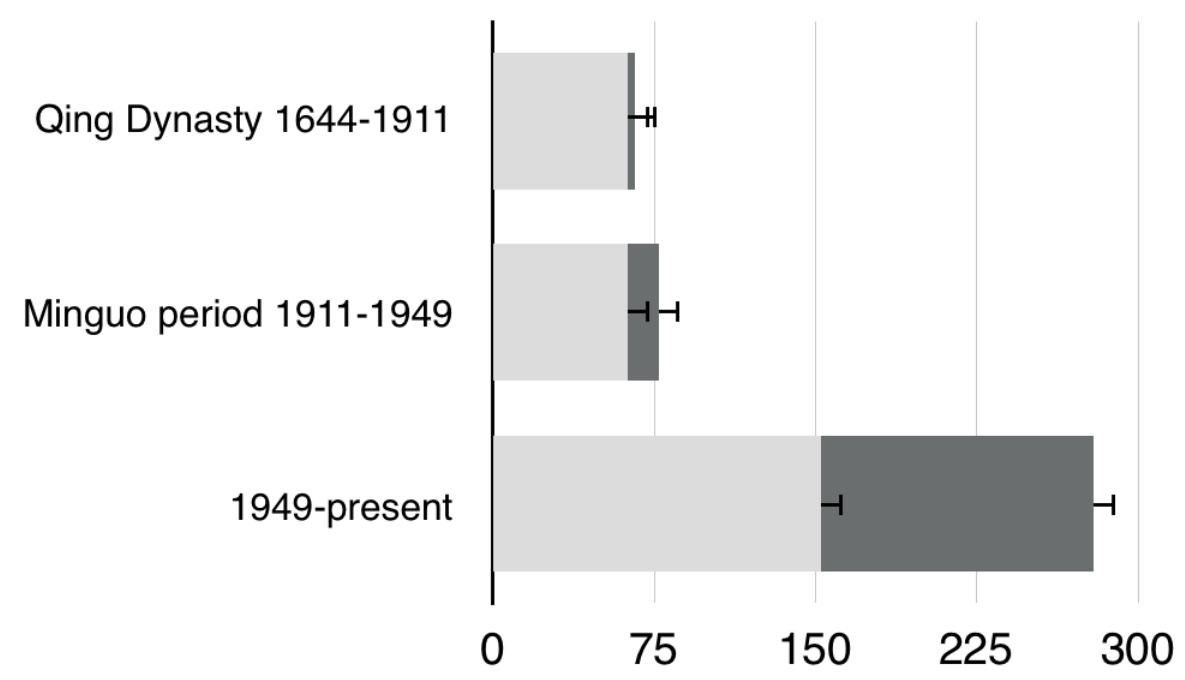

Figure 3.

\section{Assertive}

300

Semasiological comparison of directive vs assertive 吧- $b a$-CAPs from the CCL

The significant difference in the increase of assertive usage of 吧- $b a$ in comparison with the directive one $(>0.5)$ is in line with general prediction of this study: a construction that encodes OIAs occurring at the physical level is expected to progressively develop similar schemas of OIAs in the epistemic domain. This is not to say that epistemic functions of 吧- $b a$ are meant to replace directive ones (the latter have also been increasing over time), but rather to suggest that the epistemic domain is equally determined by enactive Co-act proposals as the physical one, viz. they are both fields of interested

\footnotetext{
${ }^{8}$ During the first period of early Communist rule (1949-69) the Chinese Communist Party launched a series of political campaigns and social purging to install the new ideology of 'equality', thus mounting a direct challenge to traditional Confucian ideologies. This tendency indeed correlated with the disappearance of honorifics (i.e. Kádár \& Pan 2011) and may have also played a role in the shift from negative-interrogative to plain assertive usages of 吧- $b a$.
} 
attempts to exert influence (i.e. let $u s$ do $\mathrm{p} \rightarrow$ let us believe $\mathrm{p}$ ) rather than being simply aimed at sharing information ${ }^{9}$.

\subsection{CAP-semasiology and intersubjectification}

Concerning the gradient relationship between directive and epistemic forms of OIAs, a most interesting fact is that the negative-interrogative employment of 吧- $b a$ is still more frequent than the assertive during the Qing Dynasty and seems to have served as a bridging element between directive and assertive forms of CAPs.

This is not surprising as the semasiological shift from a directive to an assertive type of illocutionary force is reasonably expected to pass through an interrogative stage (see also Bates et al. 1998 and Reich 2011: 1357 on this point), especially if the function at stake is a tag-question

\footnotetext{
${ }^{9}$ It is acknowledged that historical pragmatics in concerned with language use as such (i.e. providing the raw material on language use relevant for the analysis of language change), whereas so-called pragmatic historical linguistics pays attention to language change under shifting historical circumstances (cf. Jucker 1995: 5-6; Jucker and Taavitsainen 2013). While this study proposes an evolutionary approach to the former, it is worth considering the importance of a process cultural and linguistic anti-traditionalism gaining the upper hand after the birth of the Republic of China in 1912 and, more significantly, after the Communist takeover and the establishment of the People's Republic of China in 1949. During this period, the political shift of written media indicates abrupt changes in language use (cf. Kádár \& Pan 2011; Pan \& Kádár 2012: 8). This may have also indirectly accelerated diverse cases of ongoing semasiological change, possibly including the dramatic shift of 吧-ba uses during the 1911-1949 and 1949-present periods.
} 
employed as a request of confirmation or endorsement. This corpus-driven trend is qualitatively illustrated below:

[Directive]

（22）胜英！拿小包袱下台去吧。

Shèng Yīng! ná xiăo bāofu xiàtái qù ba

Sheng Ying! take small bundle step-down-from-the-stage BA

'Sheng Ying! Come on, take that bundle and step down from the stage.'

CCL Qing Dinasty (1644-1911) \San Xia Jian

[Negative-interrogative]

(23) 妹妹来啦, 没吃饭吧?

mèimei lái la , méi chī fàn ba

Sister come PART, not eat food BA

'Oh, sister's here! You haven't eaten yet, have you?'

CCL Qing Dinasty (1644-1911) \San Xia Jian

[Negative-interrogative]

（24）胜爷闻听一笑, 遂说道：“此人二十上下岁吧”?

shèngyé wéntīng yī xiào zhú shuōdào cǐrén èrshí shàngxià suì ba

father-Sheng hear one laugh, in-turn say this person 20 more-or-less BA

'As Sheng heard that he laughed and in turn replied: "this person will be 20 year old more or less, isn't it?",

CCL Qing Dinasty (1644-1911) \San Xia Jian

[Assertive]

(25) 牲口有十来多头吧。

shēngkǒu yǒu shí lái duō tóu ba

livestock have ten come many CLAS BA

'We can say that there are more than ten animals (here).'

CCL (1949-present) Zhou Li Bo \Baofeng Zhuoyu

In (22) $\mathrm{Sp} / \mathrm{w}$ invites $\mathrm{Ad} / \mathrm{r}$ to physically perform an action in the form of a shared project: come on, take that bundle and step down from the stage. Conversely, in (23) 吧-ba is used as a negative- 
interrogative to invite $\mathrm{Ad} / \mathrm{r}$ to confirm the state of affairs of $\mathrm{p}$ at the epistemic level, no more at the physical one. In the subsequent shift from (23) to (24) the state of affairs of p does not directly impinge on $\mathrm{Ad} / \mathrm{r}$ 's specificity anymore, as the age of that person may be guessed by that specific $\mathrm{Ad} / \mathrm{r}$ as much as anyone else would.

In (25) an assertive form of CAP is finally obtained. At this stage of semasiological reanalysis 吧- $b a$ may occur in monologues as the co-action does not even require an $\mathrm{Ad} / \mathrm{r}$ to be present. Sp/w's OIA is now realised based on construals of extended intersubjectivity E-I (cf. Tantucci 2016b, 2016d, 2017). Here it is an assumed 3rd party (3rdP) who is supposed to join this epistemic co-action of concluding that there are more than ten animals (here). In other words, $\mathrm{Sp} / \mathrm{w}$ in (26) is intersubjectively aware that a mere assertion may result in obvious non-cooperative behaviour (cf. Brown \& Levinson 1987). Yet, through the employment of 吧- $b a$ s/he markedly expects 3rdP (i.e. any other reasonable mind beyond $\mathrm{Ad} / \mathrm{r}$ ) to support his/her assertion in the form of a co-action. Finally, the most recent development of topic-introducing 吧 $b a$-CAPs constitutes a further stage of extended-intersubjectification as Sp/w assertively establishes a new topic precisely based on 3rdP's expected endorsement of this choice (see (21) in section 3.2). The intersection between intersubjectivity and co-actionality throughout the semasiological change of 吧-ba is summarised in the diagram below:

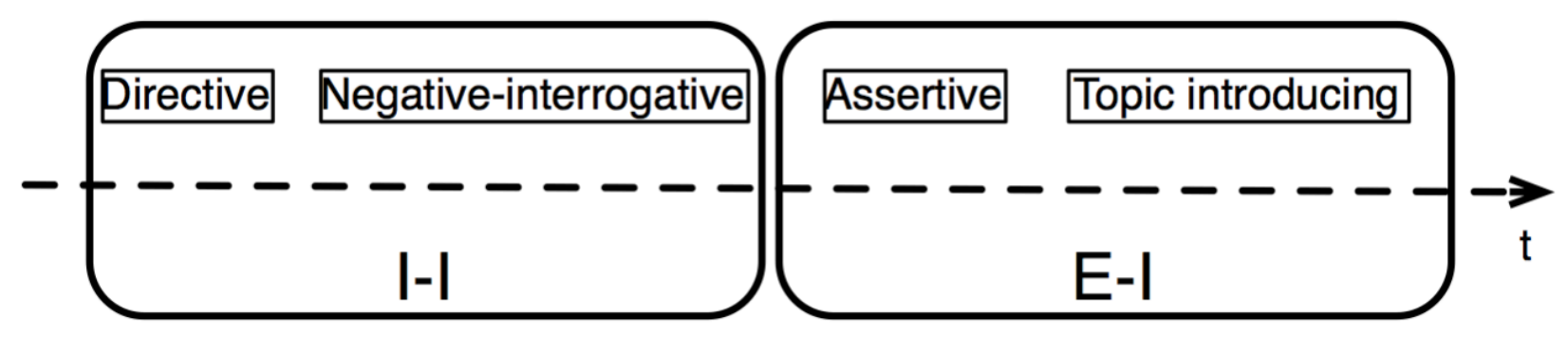

Figure 4.

Intersections of CAPs and intersubjectification through the semasiology of 吧- $b a$

Along a timeline t, a shift from I-I to E-I intersects with a semasiological change of 4 types of CAPs: directive $>$ negative-interrogative $>$ assertive $>$ topic-introducing.

\subsection{Extended-intersubjectification and text-coherence}

It is acknowledged that high degree of constructional intersubjectification may intersect with new discourse-oriented functions contributing to the textual coherence of the discourse (Narrog 2012a: 
36, 2012b). Compatibly with this, the new E-I assertive employment of 吧- $b a$ is predicted to exert influence at the discourse-level, no more impinging on physical co-actionality.

This can be shown through a collexeme analysis of both pre-and post-verbal collocates of [ $p$ 吧 $-p a]$ in the three time-spans considered. Distinctive collexeme analysis (Gries and Stefanowitsch 2004a; Hilpert 2006) draws on collostructional analysis and can be used to compare the distinctive attraction among two (or more) competitive lexemes with a construction in different periods of time. The aim of this survey is to capture the degree of attraction or repulsion of 吧- $b a$ with pre-verbal elements that profile a physical co-action rather than an epistemic OIA. In table 8 below the 2 competitive variables are respectively [a pre-verbal modifier $\alpha$ distinctively attracted to 吧- $b a$ within a -1-7L word-span] and [a proposition $\mathrm{p}$ 吧- $b a$ distinctively occurring without $\alpha$ ] in each periodised sub-corpus. The selection of $\alpha(\mathrm{s})$ is based on the rank of pre-verbal elements displaying the highest Log-dice value in -1-7L collocation with 吧-ba from the 1949-present section:

\begin{tabular}{llllllllll} 
& \multicolumn{3}{l}{$1644-1911$} & \multicolumn{4}{c}{$1911-1949$} & \multicolumn{3}{c}{ 1949-present } \\
\cline { 2 - 9 } Pre verb & $\mathrm{N}$ & Pref occ & Coll Str & $\mathrm{N}$ & Pref occ & Coll Str & $\mathrm{N}$ & Pref occ & Coll Str \\
\hline 该 gāi & 12 & other & 15,3 & 11 & other & 4,7 & 82 & 该 gāi & 30,9 \\
会 huì & 54 & other & 4,8 & 61 & other & 8,8 & 167 & 会 huì & 21,1 \\
要 yào & 85 & other & 9,6 & 63 & none & $/$ & 139 & 要 yào & 18,5 \\
大概 dàigài & 24 & other & 3,5 & 16 & none & $/$ & 75 & 大概 dàigài 3,3 \\
能 néng & 31 & other & 6,4 & 47 & none & $/$ & 66 & 能 néng 3,3 \\
快 kuài & 280 & none & $/$ & 196 & none & $/$ & 163 & none
\end{tabular}

Table 8

Distinctive collexeme analysis of 吧- $b a$ with pre-verbal elements ${ }^{10}$

Preverbal elements in Table 8 are respectively 该-gāi 'should' , 会-huì 'will-likely', 要-yào, 'must', 大概-dàgài 'probably', 能-néng 'can', 快-kuài 'fast'. Among those, the only one that during the last period (1949-present) is not distinctively attracted to a 吧-ba-CAP is 快-kuài 'fast ${ }^{, 11}$. This fact is due to the high compatibility of 快-kuài 'fast' with directive 吧-ba-CAPs, while the declarative mood is

\footnotetext{
${ }^{10}$ The columns from table 8 respectively refer to the preverbal lexeme $\alpha$; the number of occurrences $\mathrm{N}$ of $\alpha$; the preferred occurrence (whether it is significantly $\alpha$ or any other lexeme in that position) and the collostructional strength. ${ }^{11}$ A significant collostructional strength is marked with other in 1644-1911 and 1911-1949 periods. This indicates that during those periods 吧- $b a$ is distinctively attracted to 'other-than' the construction under enquiry (i.e. other than 该$g \bar{a} i 7 \mathrm{R}$ 吧- $b a$ ) when compared with 1949-present.
} 
clearly more compatible with epistemic elements as the ones listed in table 8 . That is to say, the earlier employment of 吧 $-b a$ is prominently directive, thus it tends to repel surrounding epistemic constructions. In fact, directive OIAs function in isolation in the form of physical requests directed to a specific Ad/r. Conversely, the subsequent extended-intersubjectification of 吧-ba during 1911-1949 and 1949-present intersects with OIAs that increasingly occur at the epistemic level, requiring discourse coherence and textual argumentation rather than isolated requests to exert influence. Simply put, the OIA is now more of a persuasive kind than a coercive one:

\section{(26) 我想总该不会有吧。}

wǒ xiăng zǒng gāi bù huì yǒu de ba

I think all-in-all should not will-likely have BA

'I think we can say that this will not happen.' 12

CCL (1949-present) \Prose

Similarly, in table 9 below the 2 competitive variables are respectively [a post-verbal connective $\alpha$ distinctively attracted to 吧 $b a$ within $\mathrm{a}+1+8 \mathrm{R}$ word-span] and a proposition [p 吧 $b a$ distinctively occurring without $\alpha$ ] in each periodised sub-corpus. Even here, the selection of $\alpha(s)$ is based on the rank of connectives/particles displaying the highest Log-dice value in $+1+8 \mathrm{R}$ collocation with 吧 $b a$ from the 1949-present section.

\begin{tabular}{llllllllll} 
& \multicolumn{3}{l}{$1644-1911$} & \multicolumn{3}{l}{$1911-1949$} & \multicolumn{3}{c}{ 1949-present } \\
\cline { 2 - 9 } Connector & $\mathrm{N}$ & Pref occ & Coll Str & $\mathrm{N}$ & Pref occ & Coll Str & $\mathrm{N}$ & Pref occ & Coll Str \\
\hline 再 zài & 58 & other & 12,3 & 66 & none & $/$ & 114 & 再 zài & 26,3 \\
还 hái & 75 & other & 7,3 & 62 & other & 6,5 & 166 & 还 hái & 23,9 \\
又 yòu & 110 & none & $/$ & 51 & other & 8,7 & 116 & 又 yòu & 20,4 \\
呢 ne & 23 & other & 3,2 & 18 & none & 4,6 & 71 & 呢 ne & 11,4 \\
反正 fănzhèng & 0 & other & 3,2 & 2 & other & 3,2 & 51 & 反正 tannzhing & 6,9 \\
就 jiù & 192 & other & 10,5 & 204 & none & $/$ & 163 & 就 jiù & 4,5
\end{tabular}

\footnotetext{
${ }^{12}$ The intersection of 吧- $b a$ used assertively and epistemic constructions may result in evaluational forms of CAPs (cf. Tantucci 2016a).
} 
Table 9

Distinctive collexeme analysis of 吧- $b a$ with post-verbal connectives

Not surprisingly, all post-verbal connectives binding discourse coherence in table 9 are distinctively more attracted to 吧- $b a$ during the 1949-present period than the previous time-spans. Respectively, 再-zài ‘then/again', 还-hái ‘additionally/also', 又-yòu 'again/really’, 呢-ne ‘why-not', 反正-fănzhèng ‘anyways' and 就-jiù 'then/really', all show a tendency to bind discourse coherence in connection to a previous a proposition $\mathrm{p}$ :

\section{(27) 就算天数吧，二哥今天又死了.}

jiù suàn tiānshù ba , èrgē jīntiān yòu sǐ le

really consider fate BA, second-brother today even die ASP

We can say that's destiny, not to mention that today the second brother also died.

CCL (1949-present) \Literature $\backslash$ Yu Ping Bo

The textual employment of 又-yò 'not-to-mention/really' in (27) is clearly aimed at reinforcing the assertive CAP We can say that's destiny. Once again, Sp/w's influence here is exerted on a textual rather than a physical level.

\section{Conclusions}

This paper proposes a new enactive approach to language change. The focus here is no more on how the illocutionary force of an utterance is accounted for symbolically (viz. merely aiming at sharing information). It rather lies on the phenomenology of a speech act as a process of overt influence attempt (OIA). Corpus-based evidence from the CCL shows that the semasiological change of the Mandarin sentence-final particle 吧- $b a$ shifts from physical to epistemic forms of co-act proposals. In the latter case, Sp/w's utterance is based on extended-intersubjectivity (cf. Tantucci 2013, 2016b, 2016c, 2017) and aims to exert cognitive/social influence textually, based on the awareness of a $3 \mathrm{rd}$ party as a social bearer of the utterance. The enactive approach has serious implications for a number of semantic categories and linguistics acts of the linguistic system. In particular, this study proposes that epistemic modality is not only a category indicating the degree of likelihood of some state of affairs. It is rather inherently based upon the attempt to persuade a co-agent to evaluate a proposition 
in agreement with $\mathrm{Sp} / \mathrm{w}$. The 'interested' nature of enacted communication entails a distinction between 'mere' co-actional engagement with a co-agent from more sophisticated mechanisms of immediate/extended intersubjectivity. The latter are necessarily informed by a Theory of mind (ToM) as they occur in the form marked attempts to account for other personas' emotions and beliefs as a 'surplus' over subject-oriented co-actional engagement. The distinction between co-actionality and gradient intersubjectivity is proved here to be significant for historical linguistics. Similarly, it has the potential inform new corpus-based models of analysis of ToM in early ontogeny and across the autistic spectrum distinctively tackling spontaneous interaction.

\section{References}

Austin, John Langshaw. 1962. How to do things with words. Oxford: Oxford University Press.

Bates, Elizabeth, Luigia Camaioni, and Virginia Volterra. 1975. "The acquisition of performatives prior to speech." Merrill-Palmer Quarterly of Behavior and Development 21 (3):205-226.

Bangerter, Adrian, and Herbert H Clark. 2003. "Navigating joint projects with dialogue." Cognitive Science 27 (2):195-225.

Beckner, Clay, Richard Blythe, Joan Bybee, Morten H. Christiansen, William Croft, Nick C. Ellis, John Holland, Jinyun Ke, Diane Larsen-Freeman, and Tom Schoenemann. 2009. "Language Is a Complex Adaptive System: Position Paper." In Language Is a Complex Adaptive System, edited by N. C. Ellis and D. L. Freeman. Chichester: John Wiley \& Sons.

Biber, Douglas. 1988. Variation across speech and writing. Cambridge: Cambridge University Press.

Bowles, Samuel. 2006. "Group competition, reproductive leveling, and the evolution of human altruism." Science 314 (5805):1569-1572.

Bradford, Elisabeth EF, Ines Jentzsch, and Juan-Carlos Gomez. 2015. "From self to social cognition: theory of mind mechanisms and their relation to executive functioning." Cognition 138:21-34.

Brown, Penelope, and Stephen C. Levinson. 1987. Politeness: Some universals in language usage. Vol. 4: Cambridge University Press.

Chao, Yuen Ren. 1968. A grammar of spoken Chinese. Oakland: University of California Press.

Clark, Herbert H. 1996. Using language, Cambridge University Press. Cambridge.

Clark, Andy. 2008. Supersizing the mind: Embodiment, action, and cognitive extension. New York: OUP USA.

Clark, Herbert H., and S. A. Brennan. 1991. "Grounding in communication." In Perspectives on socially shared cognition, edited by L.B. Resnick, J.M. Levine and S.D. Teasley. Washington: APA Books.

Croft, William. 2000. Explaining language change: An evolutionary approach. Harlow: Pearson Education.

Croft, William. 2007. "The origins of grammar in the verbalization of experience." Cognitive Linguistics 18 (3):339-382.

Culpeper, Jonathan and Kyto Merja. 2010. Early modern English dialogues: Spoken interaction and writing. Cambridge: Cambridge University Press.

De Smet, Hendrik. 2012. "The course of actualization." Language 88 (3):601-633.

Engel, Andreas K., Karl J. Friston, and Danica Kragic. 2014. "Where's the action?" In The pragmatic turn: Toward action-oriented views in cognitive science, edited by Andreas K. Engel, Karl J. Friston and Danica Kragic. Cambridge/London: MIT. 
Geeraerts, Dirk. 1997. Diachronic prototype semantics: A contribution to historical lexicology. Oxford: Clarendon.

Ghesquière, Lobke, and Freek Van de Velde. 2011. "A corpus-based account of the development of English such and Dutch zulk: Identification, intensification and (inter) subjectification." Cognitive Linguistics 22 (4):765-797.

Gries, Stefan Th. 2015. "More (old and new) misunderstandings of collostructional analysis: On Schmid and Küchenhoff (2013)." Cognitive Linguistics 26 (3):505-536.

Gries, Stefan Th, and Anatol Stefanowitsch. 2004. "Extending collostructional analysis: A corpusbased perspective onalternations'." International journal of corpus linguistics 9 (1):97-129.

Guardamagna, Caterina. 2017. "Reportative evidentiality, attribution and epistemic modality: A corpus-based diachronic study of Latin secundum NP ('according to NP')." Language Sciences 59:159-179.

Henrich, Natalie, and Joseph Patrick Henrich. 2007. Why humans cooperate: A cultural and evolutionary explanation: Oxford University Press.

Hilpert, Martin. 2006. "Distinctive collexeme analysis and diachrony." Corpus Linguistics and Linguistic Theory 2 (2):243-256.

$\mathrm{Hu}$, Ming Yang. 1981. "Beijinghua de yuqici he tanci." Zhonguo Yuwen 5 (6): 416-423.

Hurford, James R. 1974. "Exclusive or inclusive disjunction." Foundations of language 11 (3):409411.

Jing-Schmid, Zhuo, and Xinjia Peng. 2016. "The emergence of disjunction: A history of constructionalization in Chinese." Cognitive Linguistics 27 (1):101-136.

Jucker, Andreas H. 1995. Historical pragmatics: Pragmatic developments in the history of English. Vol. 35. Amsterdam: John Benjamins Publishing.

Jucker, Andreas H, and Irma Taavitsainen. 2013. Historical pragmatics. Berlin: Walter de Gruyter.

Kádár, Z. Dániel, and Michael Haugh. 2013. Understanding politeness. Cambridge: Cambridge University Press.

Kádár, Z. Dániel, and Yu Lin Pan. 2012. "Politeness in China." In Politeness in East Asia, edited by Dániel Z. Kádár and Sara Mills, 125-146. Cambridge: Cambridge University Press.

Kissine, Mikhail. 2013. From utterances to speech acts. Cambridge: Cambridge University Press.

Koschmann, Timothy, and Curtis D LeBaron. 2003. "Reconsidering Common Ground." ECSCW 2003, Helsinki.

Lan Ying. 2004. "Cong Yuanzaju kan xiandaihanyu de juwei yuqici." Guangdong dianshidaxue xuebao (2):86-88.

Langacker, Ronald W. 1990. "Subjectification." Cognitive Linguistics 1 (1):5-38.

Langacker, Ronald W. 2006. "Subjectification, grammaticization, and conceptual archetypes." In Subjectification: Various paths to subjectivity, edited by A. Athanasiadou, C. Canakis and B. Cornillie, 17-40. Berlin/New York: Mouton de Gruyter.

Lenker, Ursula. 2016. "'This, of course, is a popular subject ...': Subjectivity and intersubjectivity with initial, medial and final epistemic stance adverbials in English." International Conference of English Historical Linguistics, Essen, 2016.

Li, Charles, and Sandra A. Thompson. 1981. Mandarin Chinese: A functional reference grammar. Berkeley: University of California Press.

Lu, Jian Ming. 1984. "Guanyu xiandaihanyuli de yiwenyuqici." Zhongguo Yuwen 5: 330-337.

Lü, Shu Xiang. 1980. Xiandai Hanyu babaici. Beijing: Shangwu yinshuguan.

Narrog, Heiko. 2012a. "Beyond intersubjectification: Textual usages of modality and mood in subordinate clauses as part of speech orientation." English Text Construction 5 (1):29-52.

Narrog, Heiko. 2012b. Modality, subjectivity, and semantic change: A cross-linguistic perspective. Oxford: Oxford University Press.

Noë, Alva. 2004. Action in perception: MIT press.

Nuyts, Jan. 2012. "Notions of (inter) subjectivity." English Text Construction 5 (1):53-76.

Spencer-Oatey, Helen. 2005. "(Im) politeness, face and perceptions of rapport: Unpackaging their bases and interrelationships." Journal of Politeness Research 1 (1):95-119. 
Olson, David R. 1994. The world on paper: The conceptual and cognitive implications of reading and writing. Cambridge: Cambridge University Press.

Pan, Yuling, and Dániel Z. Kádár. 2011. Politeness in historical and contemporary Chinese. London: A\&C Black.

Pascual, Esther. 2006. "Fictive interaction within the sentence: A communicative type of fictivity in grammar." Cognitive linguistics 17 (2):245-267.

Qi, Shi Yang. 2002. Yuqici yu yuqixitong: Anhui Jiaoyu Chubanshe.

Qu, Cheng Xi and Li Peng. 2004. "Lun xiandaihanyu jumoqingtaixuci jiqi yingyi": yi "ba" de yupian gongneng weili." Waiyu Xuekan 6:1-10.

Reich, Wendelin. 2011. "The cooperative nature of communicative acts." Journal of Pragmatics 43 (5):1349-1365.

Reich, Wendelin. 2012. "In defense of the evolutionary approach to human communication: Reply to Huang and Wu." Journal of Pragmatics 44 (1):123-125.

Rychlý, Pavel. 2008. "A lexicographer-friendly association score." Proceedings of Recent Advances in Slavonic Natural Language Processing, RASLAN:6-9.

Shao, Jing Min. 1996. Xiandai Hanyu yiwenju yanjiu. Shanghai: Hudong Shifan Daxue Chubanshe.

Schilbach, Leonhard, Bert Timmermans, Vasudevi Reddy, Alan Costall, Gary Bente, Tobias Schlicht, and Kai Vogeley. 2013. "Toward a second-person neuroscience." Behavioral and Brain Sciences 36 (04):393-414.

Schmid, Hans-Jörg. 2016. "Why Cognitive Linguistics must embrace the social and pragmatic dimensions of language and how it could do so more seriously." Cognitive Linguistics 27 (4):543-557.

Schneider, Dana, Virginia P Slaughter, and Paul E Dux. 2015. "What do we know about implicit false-belief tracking?" Psychonomic bulletin \& review 22 (1):1-12.

Searle, John R. 1969. Speech acts: An essay in the philosophy of language. Vol. 626. Cambridge: Cambridge University press.

Searle, John R, and Daniel Vanderveken. 1985. Foundations of illocutionary logic. Cambridge: Cambridge Universirty Press.

Stefanowitsch, A., and S. T. Gries. 2003. "Collostructions: investigating the interaction of words and constructions." Int J Corpus Linguist 8. doi: 10.1075/ijcl.8.2.03ste.

Shie, Chi-chiang. 1991. "A Discourse-functional analysis of Mandarin sentence-final particles." MA thesis, National Chengchi University

Sun, Xi Xin. 1999. Jindai Hanyu yuqici. Beijing: Yuwen Chubanshe.

Tantucci, Vittorio. 2013. "Interpersonal Evidentiality: The Mandarin V-过 guo construction and other evidential systems beyond the "source of information'." Journal of Pragmatics 57:210-230.

Tantucci, Vittorio. 2015a. "Traversativity and grammaticalization: The aktionsart of 过 guo as a lexical source of evidentiality." Chinese Language and Discourse 6 (1):57-100.

Tantucci, Vittorio. 2015b. "Epistemic inclination and factualization: a synchronic and diachronic study on the semantic gradience of factuality." Language and Cognition 7 (3):371-414.

Tantucci, Vittorio. 2016a. "Towards a typology of constative speech acts: Actions beyond evidentiality, epistemic modality and factuality." Intercultural Pragmatics 13 (2).

Tantucci, Vittorio. 2016b. "Textual factualization: The phenomenology of assertive reformulation and presupposition during a speech event." Journal of Pragmatics 101:155-171.

Tantucci, Vittorio. 2016c. "The factualization of 'I suppose' in American English: a corpus based study of the subjectification of epistemic predicates toward factuality." SpringerPlus 5 (1): 1773. doi: 10.1186/s40064-016-3438-0.

Tantucci, Vittorio. 2016d. "Immediate and extended intersubjectification in language change: Beyond the Opposition between "Theory-Theory" and "Simulation-Theory"." In Dualism, Platonism and Voluntarism: Explorations at the Quantum, Microscopic, Mesoscopic and Symbolic Neural Levels, edited by Sean O'Nuallain, 81-107. Newcastle: Cambridge Scholars Publishing. 
Tantucci, Vittorio. 2017. "From immediate to extended intersubjectification: A gradient approach to intersubjective awareness and semasiological change." Language and Cognition 9 (1):88120.

Terkourafi, Marina. 2015. "Conventionalization: A new agenda for im/politeness research." Journal of Pragmatics 86:11-18.

Tomasello, Michael. 2009. The cultural origins of human cognition. Harvard: Harvard University Press.

Traugott, Elizabeth C. 2012. "Intersubjectification and clause periphery." English Text Construction 5 (1):7-28.

Traugott, E. C., and R. B. Dasher. 2002. Regularity in semantic change. Cambridge: Cambridge University Press.

Van Olmen, Daniël. 2017. "A diachronic corpus study of prenominal zo'n 'so a'in Dutch Pathways and (inter) subjectification." Functions of language 24 (3).

Varela, FJ, ET Thompson, and E Rosch. 1992. The Embodied Mind: Cognitive science and human experience (new edition edition.). Cambridge, Ma: The MIT Press.

Vidal, E. Victoria. 1998. "Politeness: A relevant issue for relevance theory." Revista alicantina de estudios ingleses, (11):45-57.

Wang, Li 1984. Wangli wenji. Jinan: Shangdong Jiaoyu Chubanshe.

Wang, Wen Fang. 2009. Xiandai Hanyu yuqici "ba" yanjiu zongshu. Yancheng Shifanxueyan Xuebao 2:87-89.

Wiedenhof, Jeroen. 2015. A grammar of Mandarin. Amsterdam/Philadelphia: John Benjamins Publishing Company.

$\mathrm{Xu}$, Jing Ning. 2008. Xiandaihanyu huayu qingtai yanjiu. Beijing: Kunlun Chubanshe. 